\title{
Olleya marilimosa gen. nov., sp. nov., an exopolysaccharide-producing marine bacterium from the family Flavobacteriaceae, isolated from the Southern Ocean
}

\author{
Correspondence \\ Carol Mancuso Nichols \\ C.A.Mancuso@utas.edu.au
}

\author{
Carol Mancuso Nichols, ${ }^{1}$ John P. Bowman ${ }^{2}$ and Jean Guezennec ${ }^{3}$ \\ ${ }^{1}$ School of Agricultural Science, University of Tasmania, Hobart, Tasmania, Australia \\ ${ }^{2}$ Australian Food Safety Center of Excellence, University of Tasmania, Hobart, Tasmania, \\ Australia \\ ${ }^{3}$ Institut Français de Recherche pour l'Exploitation de la Mer, Centre de Brest, DRV/VP/BMM, \\ Plouzané, France
}

\begin{abstract}
A Gram-negative, aerobic, gliding, orange-yellow marine bacterium was isolated from particulate material sampled from the Southern Ocean. This strain produced an exopolysaccharide in liquid culture. 16S rRNA gene sequence analysis showed that this isolate was a member of the family Flavobacteriaceae, but represented a separate lineage. Major whole-cell fatty acids included i15: $1 \omega 10 c$, i15:0, $\beta-\mathrm{OH}$ i15:0, a15: $1 \omega 10 c, 15: 0$ and $\alpha-\mathrm{OH}$ i15:0. The $\mathrm{G}+\mathrm{C}$ content of the DNA was $49 \mathrm{~mol} \%$. Based on phylogenetic, phenotypic, chemotaxonomic and genotypic analyses, this bacterium was placed in a novel taxon as Olleya marilimosa gen. nov., sp. nov. with type strain $\mathrm{CAM030}^{\top}\left(=\mathrm{ACAM} 1065^{\top}=\mathrm{CIP} 108537^{\top}\right)$.
\end{abstract}

The family Flavobacteriaceae (Bernardet et al., 2002) is one of the major branches of the Gram-negative phylum 'Bacteriodetes' that has been known until recently as the Cytophaga-Flexibacter-Bacteroides (CFB) group (Garrity \& Holt, 2001). Within this family, 16S rRNA gene sequence phylogenetic analyses have shown that many marine species cluster into a well-defined 'marine clade', which dominates marine and marine-derived surface waters (Bowman \& Nichols, 2005). In the world's oceans, members of the 'marine clade' of the Flavobacteriaceae make a significant contribution to the remineralization of organic matter (Kirchman, 2002). Community structure studies of microbial assemblages in the Southern Ocean have shown that this group forms a substantial proportion of the heterotrophic microbial biomass (Simon et al., 1999).

Marine aggregates are ubiquitous and abundant in the world's oceans (Fowler \& Knauer, 1986) and consist of complex assemblages of zooplankton faecal pellets, phytoplankton and other material enriched in bacterial communities (Logan \& Hunt, 1987; Mueller-Niklas et al., 1994) dominated by members of the family Flavobacteriaceae (Kirchman, 2002). As centres of high bacterial activity,

Abbreviation: EPS, exopolysaccharides.

The GenBank/EMBL/DDBJ accession number for the 16S rRNA gene sequence of strain $\mathrm{CAMO}^{\top} \mathrm{T}^{\top}$ is $\mathrm{AY} 586527$.

The whole-cell fatty acid profile of $\mathrm{CAM} 3 \mathrm{O}^{\top}$ compared with those of related genera is available as a supplementary table in IJSEM Online. marine aggregates are believed to have a major role in the downward transport of carbon (Kiorboe, 2001). In the Ross Sea near Antarctica, concentrations of aggregates were found to be greater than at most other locations in the oceans (Asper \& Smith, 2003) and aggregate sinking accounted for a significant proportion of transport of organic material to bottom waters and sediments. Exopolysaccharides (EPS) secreted by bacteria are among the polymeric substances that provide a network to hold these structures together (Flemming \& Wingender, 2001).

The availability of iron $\left(\mathrm{Fe}^{3+}\right)$ as a trace metal is of critical importance in the Southern Ocean where it is known to limit primary production (Scharek et al., 1997). As much as $99 \%$ of dissolved iron in the ocean is bound to organic ligands (Rue \& Bruland, 1995). Results from a recent study indicated that the EPS produced by one Antarctic bacterial isolate, designated $\mathrm{CAM} 030^{\mathrm{T}}$, derived from Southern Ocean particulate material included uronic acids (Mancuso Nichols et al., 2005). These monosaccharide components are negatively charged at seawater $\mathrm{pH}$, give the EPS a 'sticky' quality (Decho, 1990; Sutherland, 2001) and may influence the availability of trace metals such as iron. EPS similar to those produced by CAM $030^{\mathrm{T}}$ may be acting as ligands for cations such as iron and other trace metals in the Southern Ocean environment.

Phylogenetic analysis of strain CAM $030^{\mathrm{T}}$ showed that this bacterium belongs to the family Flavobacteriaceae, but 
represents a separate lineage (Mancuso Nichols et al., 2005). In the current study, we provide results of chemotaxonomic, genomic and phenotypic studies that support the placement of this strain in a novel taxon, Olleya marilimosa gen. nov., sp. nov., in the family Flavobacteriaceae.

Samples for isolation of bacteria were obtained during the November/December 2001 voyage of RSV Aurora Australis. CAM $030^{\mathrm{T}}$ was isolated from material sampled from the cod end of a plankton net $(20 \mu \mathrm{m})$ trawled through the Southern Ocean at approximately $65^{\circ} 32^{\prime} 06^{\prime \prime} \mathrm{S} 143^{\circ} 10^{\prime} 16^{\prime \prime} \mathrm{E}$, where the sea temperature was $4{ }^{\circ} \mathrm{C}$ and salinity was $3.5 \%$. Isolations were carried out according to methods described in Mancuso Nichols et al. (2005).

Phenotypic methods used to characterize strain CAM030 ${ }^{\mathrm{T}}$ have been described by Bowman et al. $(1996,1997)$. Unless otherwise specified, marine agar $[1 \mathrm{~g}$ yeast extract (Oxoid L21); 5 g bacteriological peptone (Oxoid L37); $32 \mathrm{~g}$ artificial sea salts (Sigma S9883); $15 \mathrm{~g}$ agar; $1000 \mathrm{ml}$ distilled water] was used as a basal medium and incubations were carried out at $20^{\circ} \mathrm{C}$. Motility was tested using the hanging drop method and gliding motility was examined after growing the strain for $1-2$ days at $12{ }^{\circ} \mathrm{C}$ on $0 \cdot 1 \times$ marine agar (solidified with $1 \%$ agar). After incubation, growth margins were observed by using phase-contrast microscopy (Bowman et al., 2003). Media used in testing for hydrolysis of starch, tyrosine, xanthine, crystalline cellulose, aesculin and elastin and for utilization of uric acid were supplemented with $3 \cdot 2 \%(\mathrm{w} / \mathrm{v})$ artificial sea salts (Atlas, 1993). DNA hydrolysis was tested by using DNase test agar (Oxoid CM321). Lipase activity and Tween 80 and casein hydrolysis were tested as described by Smibert \& Krieg (1994). Acid production from glucose was determined according to the method described by Leifson (1963). Additional biochemical tests were carried out using API 20E, API 20NE and Rapid ID 32A strips (bioMérieux) according to the manufacturer's instructions and as described by Bowman et al. (1996). For these tests, inoculating or suspension media contained $3 \cdot 2 \%(\mathrm{w} / \mathrm{v})$ artificial sea salts. API $20 \mathrm{E}$ and API 20NE strips were incubated at $20^{\circ} \mathrm{C}$ for 3 days, whereas Rapid ID 32A strips were incubated for $24 \mathrm{~h}$ at $20^{\circ} \mathrm{C}$. The results of these phenotypic tests are given in the species description.

$16 \mathrm{~S}$ rRNA gene sequence analysis of CAM $030^{\mathrm{T}}$ was carried out according to procedures described by Bowman et al. (1996) and Mancuso Nichols et al. (2005). The phylogenetic tree constructed (see Fig. 1) included 16S rRNA gene sequences from Flexibacter flexilis ATCC $23079^{\mathrm{T}}$ (GenBank accession no. M62794) and Chlorobium limicola UdG-6037 (AJ299414) as outgroups. Bootstrap analysis was performed with 500 resampled datasets by using the SEQBOOT and CONSENSE programs within the PHYLIP package (Felsenstein, 1993). High molecular mass DNA for determination of the $\mathrm{G}+\mathrm{C}$ content was extracted using the technique of Marmur \& Doty (1962). The G $+\mathrm{C}$ content was determined by the thermal denaturation procedure using spectrophotometry (Bowman et al., 1998; Sly et al., 1986).

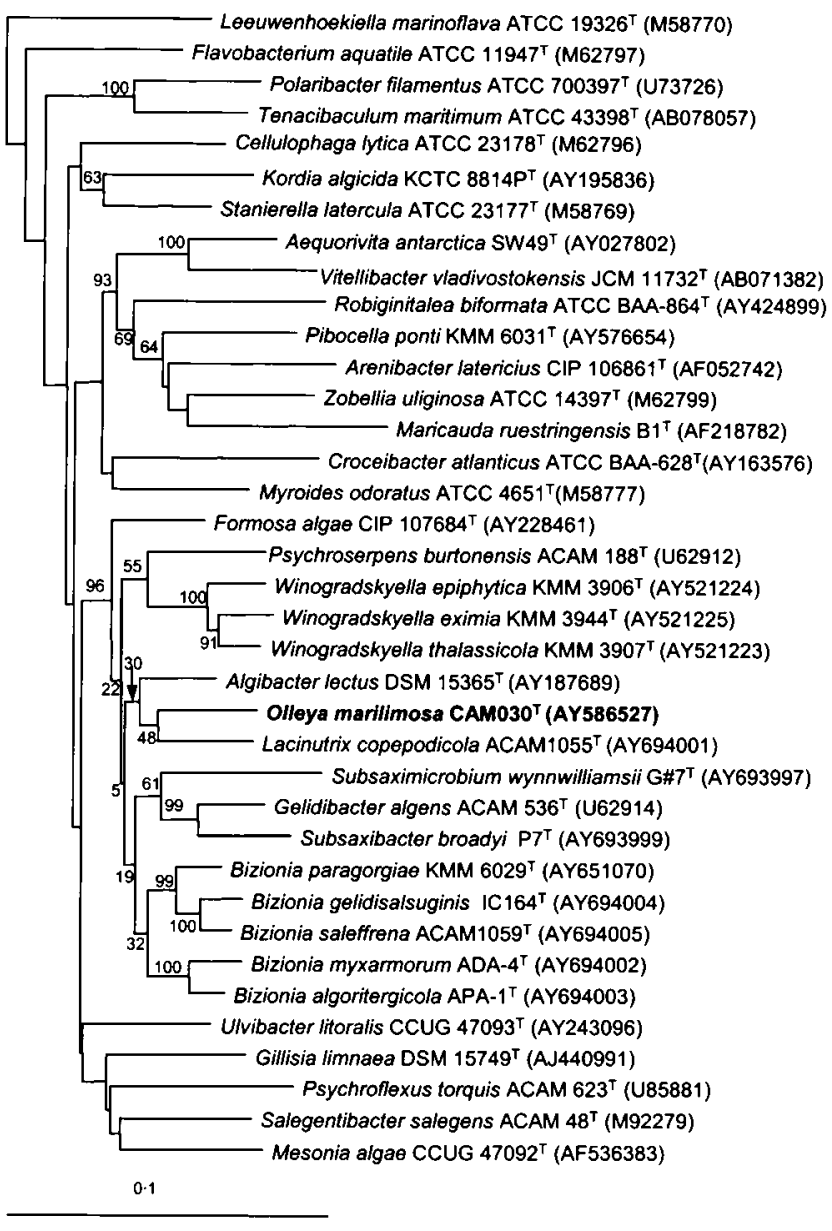

Fig. 1. Phylogenetic relationship of Antarctic marine bacterial isolate $\mathrm{CAM} 030^{\top}$ within the family Flavobacteriaceae. The tree is based on 16S rRNA gene sequences (positions 31-1470, Escherichia coli numbering scheme) and was created using maximum-likelihood distances clustered by the neighbourjoining method. Numbers in parentheses are GenBank nucleotide accession numbers. 16S rRNA gene sequences from Flexibacter flexilis ATCC $23079^{\top}$ (M62794) and Chlorobium limicola UdG-6037 (AJ299414) were used as outgroups (not shown). Bar, $0 \cdot 1$ changes per mean nucleotide position.

16S rRNA gene sequence analysis indicated that CAM $030^{\mathrm{T}}$ was distinct from all recognized members of the family Flavobacteriaceae. Lacinutrix copepodicola ACAM $1055^{\mathrm{T}}$, Bizionia saleffrena ACAM $1059^{\mathrm{T}}$, Bizionia paragorgiae KMM $6029^{\mathrm{T}}$ and Algibacter lectus DSM $15365^{\mathrm{T}}$ were the most closely related bacteria with sequence similarities of $94 \cdot 0,94 \cdot 1,94 \cdot 2$ and $94 \cdot 5 \%$, respectively (Fig. 1). The low bootstrap support $(<50 \%)$ for the $16 \mathrm{~S}$ rRNA gene sequence of CAM $030^{\mathrm{T}}$ with other related members of the family Flavobacteriaceae further suggests that $\mathrm{CAM} 030^{\mathrm{T}}$ represents a discrete taxon. Characteristics used to differentiate $\mathrm{CAM} 030^{\mathrm{T}}$ from other closely related genera within this family are shown in Table 1 . The $\mathrm{G}+\mathrm{C}$ content of the DNA 
Table 1. Differential characteristics of Olleya marilimosa gen. nov., sp. nov. CAM $030^{\top}$ and related genera belonging to the family Flavobacteriaceae

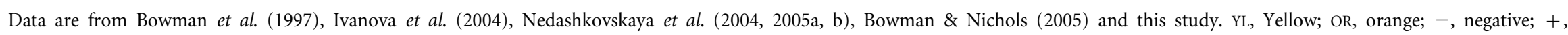

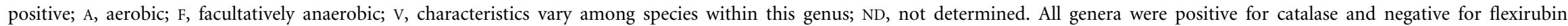
pigments, growth at $37^{\circ} \mathrm{C}$, production of indole and urease and degradation of crystalline cellulose.

\begin{tabular}{|c|c|c|c|c|c|c|c|c|}
\hline Characteristic & CAM030 $^{\mathrm{T}}$ & Psychroserpens & Gelidibacter & Lacinutrix & Algibacter & Formosa & Winogradskyella & Bizionia \\
\hline Cell morphology & $\begin{array}{l}\text { Rods with } \\
\text { tapered ends }\end{array}$ & $\begin{array}{l}\text { Ring shaped, helical } \\
\text { or coiled cells }\end{array}$ & Rods & $\begin{array}{l}\text { Straight or slightly } \\
\text { curved rods }\end{array}$ & Rods & $\begin{array}{l}\text { Slightly pointed } \\
\text { rods }\end{array}$ & Rods & Rods \\
\hline Pigment production & $\mathrm{OR} / \mathrm{YL}$ & $\mathrm{YL}$ & $\mathrm{YL} / \mathrm{OR}$ & $\mathrm{YL}$ & OR & $\mathrm{YL}$ & YL & YL \\
\hline Gliding motility & + & - & + & - & + & + & + & - \\
\hline Requirement of $\mathrm{Na}^{+}$ & + & + & $\mathrm{V}$ & + & + & - & + & + \\
\hline Growth at $25^{\circ} \mathrm{C}$ & + & - & $\mathrm{v}$ & $\mathrm{V}$ & + & + & + & $\mathrm{V}$ \\
\hline Growth at $30^{\circ} \mathrm{C}$ & + & - & - & - & + & + & + & $\mathrm{V}$ \\
\hline Metabolism & A & A & A & A & $\mathrm{F}$ & A & A & A \\
\hline Acid production from carbohydrates & + & - & $\mathrm{V}$ & - & + & + & $\mathrm{v}$ & - \\
\hline Acid production from glucose & + & - & + & - & + & + & $\mathrm{v}$ & - \\
\hline \multicolumn{9}{|l|}{ Production of: } \\
\hline DNase & - & - & $\mathrm{V}$ & - & - & ND & $\mathrm{V}$ & $\mathrm{V}$ \\
\hline Oxidase & + & - & - & - & + & - & + & + \\
\hline$\beta$-Galactosidase & - & ND & $\mathrm{V}$ & - & + & ND & - & - \\
\hline Nitrate reduction & - & - & $\mathrm{V}$ & - & - & + & - & - \\
\hline Carbohydrate utilization & + & - & + & + & + & + & $\mathrm{V}$ & - \\
\hline \multicolumn{9}{|l|}{ Degradation of: } \\
\hline Agar & - & - & - & - & + & - & + & - \\
\hline Starch & - & - & $\mathrm{V}$ & - & + & + & $\mathrm{V}$ & - \\
\hline Aesculin & - & - & $\mathrm{V}$ & - & ND & ND & ND & - \\
\hline Casein & - & + & $\mathrm{V}$ & - & - & - & $\mathrm{V}$ & + \\
\hline Gelatin & + & $\mathrm{V}$ & $\mathrm{V}$ & + & + & + & + & + \\
\hline $\mathrm{H}_{2} \mathrm{~S}$ production & - & - & - & - & - & - & $\mathrm{V}$ & + \\
\hline $\mathrm{G}+\mathrm{C}$ content $(\mathrm{mol} \%)$ & 49 & $27-29$ & $37-42$ & 37 & $31-33$ & $34-35$ & 35 & $38-45$ \\
\hline
\end{tabular}


of $\mathrm{CAM} 030^{\mathrm{T}}$ was $49 \mathrm{~mol} \%$, which also suggests that CAM $030^{\mathrm{T}}$ is distinct from other related species (Table 1).

Whole-cell fatty acid analysis was performed on cells of CAM030 $0^{\mathrm{T}}$ grown for 4 weeks at $12^{\circ} \mathrm{C}$ on marine agar. Extraction and analysis of whole-cell fatty acids was carried out according to procedures described by Mancuso Nichols et al. (2005). Fatty acids are designated by the total number of carbon atoms: number of double bonds, followed by the position of the double bond from the terminal $(\omega)$ end of the molecule. The suffixes $c$ and $t$ indicate cis and trans geometry and the prefixes $\mathrm{i}$ and a indicate iso and anteiso branching. The position of the hydroxyl group $(\mathrm{OH})$ may occur on the second $(\alpha)$ or third $(\beta)$ carbon from the carboxyl end of the molecule.

The major whole-cell fatty acids present in $\mathrm{CAM} 030^{\mathrm{T}}$ were i15: $1 \omega 10 c(22 \%)$, i15:0 (19\%), $\beta$-OH i15:0 (10\%), a15: $1 \omega 10 c(8 \%), 15: 0(7 \%)$ and $\alpha-\mathrm{OH}$ i15:0 $(7 \%)$. The whole-cell fatty acid profile of CAM $030^{\mathrm{T}}$ compared with those of related genera is given in Supplementary Table S1 in IJSEM Online. Major fatty acids found in CAM030 ${ }^{\mathrm{T}}$ and also found in other closely related genera, as well as in other members of the family Flavobacteriaceae, are also listed in Supplementary Table S1. The predominance of branched saturated, branched monounsaturated and branched hydroxy fatty acids is a common characteristic in the Flavobacteriaceae (Bowman et al., 1998, 2003; Nedashkovskaya et al., 2005b). It is interesting to note that for CAM $030^{\mathrm{T}}$ as well as for two closely related genera, Algibacter and Lacinutrix, there were few minor fatty acids with a chain length of other than 15 carbons, with the exception of br16:1 (5\%) and $\beta$-OH i17:0 (9\%) found in Lacinutrix and Algibacter, respectively. Variations in culture conditions can have a significant impact on the type and abundance of whole-cell fatty acids. At present, it is difficult to draw further conclusions from discrepancies in fatty acid profiles obtained from strains grown under dissimilar laboratory conditions.

Based upon the above data, we consider that strain CAM030 ${ }^{\mathrm{T}}$ represents a novel taxon in the family Flavobacteriaceae, for which the name Olleya marilimosa gen. nov., sp. nov. is proposed.

\section{Description of Olleya gen. nov.}

Olleya (Ol.ley'a. N.L. fem. n. Olleya named in honour of June Olley, who has made significant contributions to the area of predictive microbiology).

Cells are Gram-negative rods, approximately $0 \cdot 3-0 \cdot 5 \mu \mathrm{m}$ in width and $2 \cdot 0-2 \cdot 5 \mu \mathrm{m}$ in length. Motile by gliding. Endospores are not formed. Cell mass is orange/yellow. Flexirubin pigments are absent. Strictly aerobic chemoheterotrophs. Produce catalase. Produce acid from carbohydrates. Major fatty acids include $\mathrm{i} 15: 1 \omega 10 c$, i15: $0, \beta$-OH i15: 0 , a15: $1 \omega 10 c, 15: 0$ and $\alpha-\mathrm{OH}$ i15:0. Phylogenetically, the genus is a member of the family Flavobacteriaceae, class
Flavobacteria, phylum 'Bacteriodetes'. The type species is Olleya marilimosa.

\section{Description of Olleya marilimosa sp. nov.}

Olleya marilimosa (mar.i.lim.o'sa. L. gen. neut. n. maris of the sea; L. adj. limosus - $a$-um full of slime, slimy; N.L. fem. adj. marilimosa of the sea and slimy).

Description is as for the genus with the following additions. When incubated on marine agar for 1 week at $20{ }^{\circ} \mathrm{C}, \mathrm{CAM} 030^{\mathrm{T}}$ forms orange/yellow, translucent colonies 1-2 $\mathrm{mm}$ in diameter, circular, convex, with an entire edge and a butyrous consistency. Colonies exhibit spreading margin on dilute agar and enhanced mucoid morphology when grown on marine agar supplemented with $3 \%$ glucose. Growth occurs in the $\mathrm{pH}$ range 5-9 and in the temperature range $4-30^{\circ} \mathrm{C}$. No growth occurs at $37^{\circ} \mathrm{C}$. Requires $\mathrm{Na}^{+}$or sea salts for growth. Growth occurs between 0.2 and $0.9 \mathrm{M} \mathrm{NaCl}$ with optimal growth occurring at approximately $0 \cdot 2-0 \cdot 5 \mathrm{M} \mathrm{NaCl}$. Requires yeast extract or peptone for growth. Produces acid from glucose, assimilates a range of carbohydrates, but does not reduce nitrate to nitrite or produce $\mathrm{H}_{2} \mathrm{~S}$. Indole, DNase, $\beta$-galactosidase, lipase, urease and acetoin (Vogues-Proskauer reaction) are not produced, but oxidase and catalase are formed. Tween 80, elastin, gelatin and tyrosine are degraded, but agar, starch, aesculin, casein, cellulose and xanthine are not. Citrate is utilized as a sole carbon source, but uric acid is not. Glucose, maltose and mannose are assimilated; arabinose, mannitol, D-gluconate, capric acid, adipic acid, malate and trisodium citrate are not. Tests for $\beta-N$ acetyl-glucosaminidase, alkaline phosphatase, arginine arylamidase, leucyl glycine arylamidase, phenylalanine arylamidase, leucine arylamidase, tyrosine arylamidase, alanine arylamidase, glycine arylamidase, histidine arylamidase, glutamyl glutamic acid arylamidase and serine arylamidase are positive. Tests for arginine dihydrolase, lysine decarboxylase, ornithine decarboxylase, tryptophan deaminase, $\alpha$-galactosidase, $\beta$-galactosidase, $\beta$-galactosidase- 6 phosphate, $\alpha$-glucosidase, $\beta$-glucosidase, $\alpha$-arabinosidase, $\beta$-glucuronidase, glutamic acid decarboxylase, $\alpha$-fucosidase, proline arylamidase and pyroglutamic acid arylamidase are negative. The G $+\mathrm{C}$ content of the DNA is $49 \mathrm{~mol} \%$.

The type strain, $\quad$ CAM030 $0^{\mathrm{T}} \quad\left(=\mathrm{ACAM} \quad 1065^{\mathrm{T}}=\mathrm{CIP}\right.$ $\left.108537^{\mathrm{T}}\right)$, was isolated from Southern Ocean particulate material.

\section{Acknowledgements}

The authors thank Jenny Skerratt and Andrew Pankowski for sample collection. Andrew Bissett and Guy Abell from the School of Agricultural Science at the University of Tasmania are acknowledged for assistance in the molecular laboratory. Peter Nichols from CSIRO Marine Research is thanked for his assistance with whole-cell fatty acid analyses. Danny Holdsworth managed the CSIRO GC-MS facility. We also acknowledge the efforts of two anonymous referees and those of the editor, Jean-François Bernardet, whose comments significantly improved this manuscript. We are grateful to Jean Euzéby for 
his assistance with the Latin etymology of the new bacterial names. C.M.N. was supported by a Tasmanian Post-graduate Research Scholarship and by funding provided by the Australian Antarctic Division. C. M.N. also received travel awards from the Australian Academy of Science and the French Embassy in Canberra, Australia.

\section{References}

Asper, V. L. \& Smith, W. O. (2003). Abundance, distribution and sinking rates of aggregates in the Ross Sea, Antarctica. Deep Sea Res Part I 50, 131-150.

Atlas, R. (1993). Handbook of Microbiological Media. Boca Raton, FL: CRC Press.

Bernardet, J.-F., Nakagawa, Y. \& Holmes, B. (2002). Proposed minimal standards for describing new taxa of the family Flavobacteriaceae and emended description of the family. Int J Syst Evol Microbiol 52, 1049-1070.

Bowman, J. P. \& Nichols, D. S. (2005). Novel members of the family Flavobacteriaceae from Antarctic maritime habitats including Subsaximicrobium wynnwilliamsii gen. nov., sp. nov., Subsaximicrobium saxinquilinus sp. nov., Subsaxibacter broadyi gen. nov., sp. nov., Lacinutrix copepodicola gen. nov., sp. nov., and novel species of the genera Bizionia, Gelidibacter and Gillisia. Int J Syst Evol Microbiol 55, 1471-1486.

Bowman, J. P., Cavanagh, J., Austin, J. J. \& Sanderson, K. (1996). Novel Psychrobacter species from Antarctic ornithogenic soils. Int J Syst Bacteriol 46, 841-848.

Bowman, J. P., McCammon, S. A., Brown, J. L., Nichols, P. D. \& McMeekin, T. A. (1997). Psychroserpens burtonensis gen. nov., sp. nov., and Gelidibacter algens gen. nov., sp. nov., psychrophilic bacteria isolated from Antarctic lacustrine and sea ice habitats. Int J Syst Bacteriol 47, 670-677.

Bowman, J. P., McCammon, S. A., Lewis, T., Skerratt, J. H., Brown, J. L., Nichols, D. S. \& McMeekin, T. A. (1998). Psychroflexus torquis gen. nov., sp. nov., a psychrophilic species from Antarctic sea ice, and reclassification of Flavobacterium gondwanense gen. nov., comb. nov. Microbiology 144, 1601-1609.

Bowman, J. P., Mancuso Nichols, C. \& Gibson, J. A. E. (2003). Algoriphagus ratkowskyi gen. nov., sp. nov., Brumimicrobium glaciale gen. nov., sp. nov., Cryomorpha ignava gen. nov., sp. nov. and Crocinitomix catalasitica gen. nov., sp. nov., novel flavobacteria isolated from various polar habitats. Int J Syst Evol Microbiol 53, 1343-1355.

Decho, A. W. (1990). Microbial exopolymer secretions in ocean environments: their role(s) in food webs and marine processes. In Oceanography Marine Biology Annual Review, pp. 73-153. Edited by M. Barnes. Aberdeen: Aberdeen University Press.

Felsenstein, J. (1993). PHYLIP (Phylogeny Inference Package). Distributed by the author. Department of Genome Sciences, University of Washington, Seattle, USA.

Flemming, H.-C. \& Wingender, J. (2001). Relevance of microbial extracellular polymeric substances (EPSs). Part I: Structural and ecological aspects. Water Sci Technol 43, 1-8.

Fowler, S. W. \& Knauer, G. A. (1986). Role of large particles in the transport of elements and organic compounds through the oceanic water column. Prog Oceanogr 16, 147-194.

Garrity, G. M. \& Holt, J. G. (2001). The road map to the Manual. In Bergey's Manual of Systematic Bacteriology, 2nd edn, vol. 1, pp. 119-168. Edited by D. R. Boone, R. W. Castenholtz \& G. M. Garrity. New York: Springer.
Ivanova, E. P., Alexeeva, Y. V., Flavier, S., Wright, J. P., Zhukova, N. V., Gorshkova, N. M., Mikhailov, V. V., Nicolau, D. V. \& Christen, R. (2004). Formosa algae gen. nov., sp. nov., a novel member of the family Flavobacteriaceae. Int J Syst Evol Microbiol 54, 705-711.

Kiorboe, T. (2001). Formation and fate of marine snow: small-scale processes with large scale implications. Sci Mar 65, 57-71.

Kirchman, D. L. (2002). The ecology of Cytophaga-Flavobacteria in aquatic environments. FEMS Microbiol Ecol 39, 91-100.

Leifson, E. (1963). Determination of carbohydrate metabolism of marine bacteria. J Bacteriol 85, 1183-1184.

Logan, B. E. \& Hunt, J. R. (1987). Advantages to microbes of growth in permeable aggregates in marine systems. Limnol Oceanogr 32, 1034-1048.

Mancuso Nichols, C., Garon Lardière, S., Bowman, J. P., Nichols, P. D., Gibson, J. A. E. \& Guezennec, J. (2005). Chemical characterization of exopolysaccharides from Antarctic marine bacteria. Microb Ecol (in press).

Marmur, J. \& Doty, P. (1962). Determination of the base composition of deoxyribonucleic acid from its thermal denaturation temperature. J Mol Biol 5, 109-118.

Mueller-Niklas, G., Schuster, S., Kaltenboeck, E. \& Herndl, G. J. (1994). Organic content and bacterial metabolism in amorphous aggregations of the northern Adriatic Sea. Limnol Oceanogr 39, 58-68.

Nedashkovskaya, O. I., Kim, S. B., Han, S. K. \& 7 other authors (2004). Algibacter lectus gen. nov., sp. nov., a novel member of the family Flavobacteriaceae isolated from green algae. Int J Syst Evol Microbiol 54, 1257-1261.

Nedashkovskaya, O. I., Kim, S. B., Han, S. K. \& 12 other authors (2005a). Winogradskyella thalassocola gen. nov., sp. nov., Winogradskyella epiphytica sp. nov. and Winogradskyella eximia sp. nov., marine bacteria of the family Flavobacteriaceae. Int J Syst Evol Microbiol 55, 49-55.

Nedashkovskaya, O. I., Kim, S. B., Lysenko, A. M., Frolova, G. M., Mikhailov, V. V. \& Bae, K. S. (2005b). Bizonia paragorgiae gen. nov., sp. nov., a novel bacterium of the family Flavobacteriaceae isolated from the soft coral Paragorgia arborea. Int J Syst Evol Microbiol 55, 375-378.

Rue, E. L. \& Bruland, K. W. (1995). Complexation of iron (III) by natural organic ligands in the Central North Pacific as determined by a new competitive ligand equilibrium/adsorptive cathode stripping voltametric method. Mar Chem 50, 117-138.

Scharek, R., Vanleeuwe, M. A. \& Debaar, H. J. W. (1997). Responses of Southern Ocean phytoplankton to the addition of trace metals. Deep Sea Res Part II 44, 209-227.

Simon, M., Glöckner, F. O. \& Amann, R. (1999). Different community structure and temperature optima of heterotrophic picoplankton in various regions of the Southern Ocean. Aquat Microb Ecol 18, 275-284.

Sly, L. I., Blackall, L. L., Kraat, P. C., Tian-Shen, T. \& Sangkhobol, V. (1986). The use of second derivative plots for the determination of mol\% guanine plus cytosine of DNA by the thermal denaturation method. J Microbiol Methods 5, 139-156.

Smibert, R. M. \& Krieg, N. R. (1994). Phenotypic characterization. In Methods for General and Molecular Bacteriology, pp. 611-654. Edited by P. Gerhardt, R. G. E. Murray, W. A. Wood \& N. R. Krieg. Washington, DC: American Society for Microbiology.

Sutherland, I. W. (2001). Biofilm exopolysaccharides: a strong and sticky framework. Microbiology 147, 3-9. 